\title{
ECONOMICAL HOUSING PROVISION IN CHINA (1998-2002) - A CASE STUDY OF BEIJING
}

\author{
Fan-yu MENG ${ }^{2}$, Francis WONG ${ }^{1}$, Eddie Chi Man HUI ${ }^{1}$ and Chang-chun FENG ${ }^{2}$ \\ ${ }^{1}$ Department of Building and Real Estate, the Hong Kong Polytechnic University, China \\ ${ }^{2}$ College of Environment, Peking University, China
}

Received 12 March 2004; accepted 14 June 2004

\begin{abstract}
Economical housing in China is targeted at the housing needs of middle and lower-middle income urban households. Subsidies and other preferential policies for the provision of such housing are extended by the government. Economical housing is viewed by the Chinese central government as a fundamental component of the new housing system, which was set up in 1998 following the end of the old public housing system. It has also been used as the main driver for economic growth by the Chinese central government in the past five years. In each of those years, billions of RMB from the national budget has been invested in building economical housing, with the aim of eliminating the large gap between housing prices in the open market and public affordability, as well as to support economic growth. The issue of economical housing in China is intimately tied up with political and social issues. This paper presents a thorough study of the evolution of economical housing from 1998 to 2002 in China. Beijing is chosen as a case study because it is the capital city and has one of the most important real estate markets in the country. Recommendations are also given on the future development of economical housing.
\end{abstract}

KEYWORDS: Economical housing; Housing policy; China

\section{INTRODUCTION}

After 20 years of hard effort, the main objective of China's urban housing reforms marketization, has been largely achieved. China has undergone an important transition from an old system of allocating housing to a new system in which housing is provided by the market. The market is emerging as the main channel for housing supply. The housing sector has entered a phase of development led by demand. According to statistical data from the Ministry of Construction, the proportion of housing sold to individuals was $92 \%$ in 2001 and over 94\% in 2002 (People's Daily Overseas Edition, 2003.01.02). In Beijing, this proportion was up to $95 \%$ in 2002 , according to the Beijing Statistics Bureau. The old welfare public housing system with nominal rent has been abolished. The old concept of allocating urban housing based on political class and socialist advantages has also changed. Both work units and individuals have accepted the fact that the place where urban people solve their dwelling problems is the market, not the work unit or the government. Housing is becoming part of the general living expenses of urban households.

Although economic growth has been rapid in China since the launching of economic reforms in the late 1970 s, not every household is ready to purchase their dwelling through the market. It is assumed that more than $60 \%$ of urban households in China belong to middle or low-income level groups. Purchasing 'market-price' housing is not easy for them. As they constitute the majority of the population, their satisfaction has a deep and broad meaning in 
politics and society. How to protect their advantages in a developing economy with a transitional system is one of the responsibilities of the government. A new rudimentary system of providing housing was devised in the mid1990s to push forward the marketization of urban housing, as well as to grant housing security to middle and low income households.
The new housing provision system consists of three parts: low-rental housing without ownership for the lowest income households, economical housing with ownership and subsidies by the government for middle or lower-middle income households and market-price commodity housing for high or middle-high income households. In the early years of the estab-

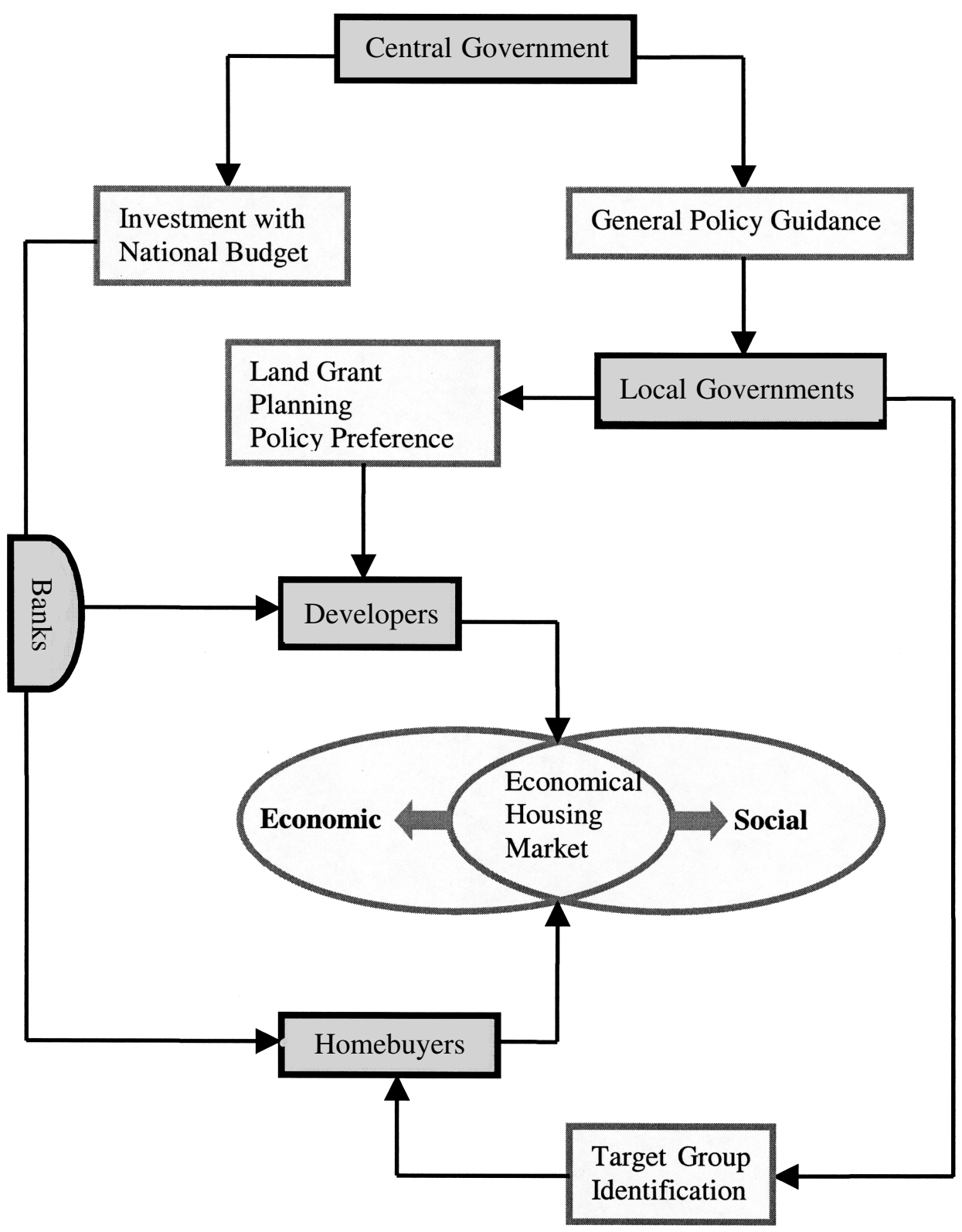

Figure 1. The Flow Chart of Economical Housing 
lishment of the new housing provision system (1995-1998), a dual-track approach was taken. Both the new and old systems co-existed, so that a cushion was given. People were psychologically prepared for a new housing market and the government had time to sort out the serious housing problems that had accumulated in the past three decades under the old housing system. On July 3, 1998, the State Council promulgated an official document, Notice on Further Deepening of the Reform of the Urban Housing System and Speeding up the Building of Housing, to notify the whole nation that the old housing system would be completely abolished nation-wide by the end of 1999. The new housing system went into full swing from that date.

Initially, the main part of the new housing system has been the provision of economical housing. It is a housing policy catering for the needs of middle income and lower-middle income households. The plan is for economical housing to make up $70 \%$ to $80 \%$ of the total supply in the housing market when the new housing system finally perfected. The government has been granting preferences to economical housing in several aspects. It has also adopted the provision of such housing as a long-term policy.

It has been five years now since economical housing was introduced in 1998. How has the scheme developed? What influence has the system of providing economical housing had on society, the economy, the real estate market and urban households in China? As the capital city and one of the most important real estate markets in the country, Beijing has been chosen as the subject of a case study on the issue. This paper aims to provide:

1. An overview of the new system of providing housing China.

2. The evolution of economical housing in China from 1998 to 2002.

3. Comments on relevant policies of the system of economical housing in Beijing.

4. An analysis of supply and demand for economical housing in Beijing.
5. Conclusions and recommendations on current economical housing policies in Beijing. The recommendations and guidelines provided on the most suitable and appropriate approach to satisfying the increasing demand for economical housing will not only be useful to government policy makers but also to housing developers. The research will provide findings that are particularly useful for the development of economical housing in Beijing and widely applicable in China.

\section{AN OVERVIEW OF CURRENT SYSTEM OF HOUSING PROVISION IN CHINA}

The new housing provision system has multiple levels of composition. There are different sub-systems for different income groups. Figure 1 shows the flow chart of the new housing provision system.

\subsection{Theoretical Basis of the Current Housing Provision System}

When the Chinese Communist Party came into power in 1949, at the top of the government's agenda was the task of developing a new socialist China. Mechanisms for the topdown control of resource allocation were established and facilitated by the nationalization of land, property and other means of production. State ownership of production became a cornerstone of the new form of governance. Private housing was gradually phased out and converted to state ownership. In the production of urban housing, government was the sole supplier, and private housing developers and investors were effectively excluded and eliminated (Zhu, 2000). As an aspect of socialist welfare, housing at nominal cost was distributed to people through administrative channels. In the late $1970 \mathrm{~s}$, a severe fiscal deficit and failing public finances led to the collapse of the old system of investment and triggered a decentralization of power. The state was unable to sustain centrally allocated investment. 
Chronic shortages of housing and unfair allocation also emerged as problems. Housing reforms, as an important part of economic reforms, were launched in 1979 to address these problems.

During the 1970s and 1980s, it has been increasingly clear in many countries that the government cannot maintain the role of a direct producer of housing, and that this role must be performed by the formal or informal private sector (World Bank, 1993). Marketization and commoditization became the main goals in the reform of China's urban housing system. Housing supply, unlike housing demand, often offers the greatest scope for reform. Since the reform of urban housing is a key component of economic reforms, principles on the distribution of market resources (i.e., distributing resources according to contribution) must have an impact on the housing sector. Housing expenditure is part of labour value and is distributed to working people in terms of wages. People purchase or rent homes in the housing market according to their level of income and personal preferences. The government intervenes in a reasonable manner in the market and provides housing security.

Housing not only has a commodity attribute, but also a social security attribute. As a commodity, housing is consumed by households by purchasing or renting in the market. But everyone has the right to have a basic dwelling. This basic dwelling will improve, along with the development of the whole socioeconomic system. According to this school of theory, a functional system of housing provision should supply housing through the market and grant private ownership. At the same time, housing security should be provided to those households who cannot afford a dwell- ing at market price. Such a system will require government, residents, financing organizations and other sectors to work together.

\subsection{The Identification of Target Groups by Level of Household Income}

A rational system for the identification of the income levels of urban households is the base for the setting up of a new housing provision system. The National Statistics Bureau has divided urban households into seven groups according to their income level. Five per cent of households are regarded as living at the poverty level (Refer to Table 1).

Although Table 1 shows a brief distribution (by percentage) of the household' income levels, it cannot give a reasonable standard for setting the cut-off point between high income and the middle income or between middle income and low income. Thus, it cannot show the actual proportion of every level.

An alternative is to divide income levels by profession and work category. Those employees, who work at governments, institutions, social organizations, enterprises and other occupations requiring considerable training and specialized study, are regarded as being in the middle-income level, and the proportions of the true income levels are being appraised. However, an exact and reasonable result cannot be obtained by using this approach, either. First, the kinds of professions are spread out so widely that it is impossible to include all categories. Second, the income level within a profession may vary substantially. Both high income and low income groups may exist within the same occupation. Third, the appearance and the disappearance of certain professions can take place within a very short period of time. The number and the structure of profes-

Table 1. Income Levels in China

\begin{tabular}{llllllll}
\hline $\begin{array}{l}\text { Income } \\
\text { level }\end{array}$ & Highest & High & $\begin{array}{l}\text { Higher } \\
\text { middle }\end{array}$ & Middle & $\begin{array}{l}\text { Lower } \\
\text { middle }\end{array}$ & Low & Lowest \\
\hline Proportion & $10 \%$ & $10 \%$ & $20 \%$ & $20 \%$ & $20 \%$ & $10 \%$ & $10 \%$ \\
\hline
\end{tabular}

(National Statistics Bureau) 
Table 2. Income Levels and Housing Provision

\begin{tabular}{llllll}
\hline \multirow{2}{*}{$\begin{array}{l}\text { Household income } \\
\text { level }\end{array}$} & $\begin{array}{l}\text { High-income } \\
\text { level }\end{array}$ & \multicolumn{2}{l}{ Middle-income level } & \multirow{2}{*}{$\begin{array}{l}\text { Low-income } \\
\text { level }\end{array}$} \\
\cline { 2 - 5 } $\begin{array}{l}\text { Annual household } \\
\text { income }\end{array}$ & Over 137,600 & $103,200 \sim 137,600$ & $68,800 \sim 103,200$ & $34,400 \sim 68,800$ & Below 34,400 \\
\hline Housing provision & Commodity housing & Economical housing & $\begin{array}{l}\text { Low-rental } \\
\text { housing }\end{array}$ \\
\hline
\end{tabular}

(Source: Compilation by the author based on the figures from $\mathrm{Di}, 2003$ )

sionals may change gradually in a modern society. Therefore, it is not easy to identify income levels using profession as a form of classification.

A more practical approach is to identify the middle-income level by the per capita income of the household. This method was put forward by a labour-wage expert of the Ministry of Labour and Social Security, Di Huang (Economic Information Daily, 2003-02-13). The cutoff point of the middle-income level should be higher than the per capita GDP and closer to the average annual wage income of employees and the international average middle-income level. It should also be at the level in which expenditures on food do not constitute more than $25 \%$ of household income. In 2002, the per capita GDP in China was about 9,000 $\mathrm{RMB}$, and the average annual wage of an employee was about $12,000 \mathrm{RMB}$. The per capita income of urban households that spend $25 \%$ of their overall living expenses on food is about 10,000 RMB. Thus, the lower limit of the per capita annual income of middle-income urban households in China can be set at 10,000 RMB. According to a study by the World Bank, the low end of the international average middleincome level is US\$3,470. After adjusting for purchasing power, this equals 14,500 RMB. The difference at 1.5 times is believable. The upper limit of the per capita annual income of middle-income urban households in China is about 40,000 RMB. There are three reasons for setting this figure as the upper limit: First, it makes the upper limit 4 times higher than the lower limit. Second, the upper limit is close to the elementary standard of the per capita
GDP in developed countries. According to the findings of the World Bank, the upper limit of the international average middle-income level is US\$8,000, which equals about 40,000 RMB after adjustment for purchasing power. Third, taking it as the cut-off point of the high-income level, the average annual income of highincome households with a double income is around 100,000 RMB. This is in accordance with the standard of high-income households in China's society at present.

In the national population census in 2000 , the average household size was 3.44 . Therefore, the income range of the middle-income households is from 34,400 to $137,600 \mathrm{RMB}$. These seven groups can be separated into three levels for a three-level system of provision. The middle-income level of from 34,400 to 137,600 RMB is also divided into three levels. According to the designers of the new provision system, economical housing should be provided for middle, lower-middle and low income groups. In Table 2, it is proposed that the income of the group targeted for economical housing should be from 34,400 to $103,200 \mathrm{RMB}$. If the annual income of a household is higher than this standard, commodity housing will become their choice. If the annual income of a family is lower than this standard, low-rental housing will be more suitable for them. The three types of housing are explained below.

\subsection{Low-rental Housing}

The system of providing low-rental housing is a system for providing housing security. The Chinese government is trying to speed up 
its system of low-rental housing provision, so as to solve the housing problem of families living in poverty. From the mid-1990s, the lowincome group in China has consisted mainly of employees who were either on/off duty in poorly operated state-owned enterprises and non-production institutes, or some retired employees. Most of these households had been distributed housing under the old housing system. Whether they own their own home or are renting, they have received a basic dwelling. Housing for them is only a problem of improvement. Thus, at present, low-rental housing is only for urban households with an income level of below the poverty line and for some disabled or elderly people without a family to provide them with housing. In April 1999, the Government had formulated 'Measures for Managing Low Rental Housing in Urban Areas', and started the system of low rental housing provision in a number of cities and towns to ensure that adequate low rental housing would be provided for the lowest-income families with housing difficulties. In 2000, the proportion of households below the poverty line was $7.5 \%$. Now, the target group for low-rental housing constitutes about $5 \%$ of all urban households. There are three strategies to the low-rental housing policy:

1. Main strategy: providing rental subsidies

2. Secondary strategy: providing low-rental housing directly

3. Tertiary strategy: giving rental rebates

The low-rental housing system has been carried out since mid-2001. It is still in a stage of infancy.

\subsection{Economical Housing}

Economical housing is the main aspect of the new system. Economical housing is a type of low-profit commodity housing with government subsidies and policy support aimed at providing a large number of decent homes for middle and lower-middle income households. Attention is paid to both marketization and social security. The market mechanism is the basic principle in the distribution of resources in economical housing. The interplay between demand and supply in the market determines the development of economical housing. The social security attribute of economical housing does not conflict with, but rather complements, the attribute of marketization. It is completely different from the old system of welfare housing under the planned economy. China is currently accelerating its levels of urbanization and industrialization. The income of residents is becoming diversified and disparities are growing. The Government is giving a helping hand to middle and lower-middle income households who are the majority of the population by specific preferential policies, which can potentially lead to an explosion in demand for housing and to an efficient expansion of housing supply.

\subsection{Commodity Housing}

Commodity housing is the most vigorous and efficient aspect of the three sub-systems. Commodity housing is housing that is invested in and built by private developers according to principles of the market economics. The supply, sale prices and building standards depend on market demand and affordability. The ownership of commodity housing is not limited in the least. Residents can buy commodity housing as residential consumption or as marketable investment. Commodity housing offers households the greatest choice and poses the greatest competition to developers (Cheng and Liu, 1999). Commodity housing is a reflection of the marketization and commoditization of the new system of housing provision.

\section{EVOLUTION OF THE ECONOMICAL HOUSING SYSTEM}

The policy on economical housing was developed as China's urban housing reforms deepened. The very first presentation of the concept was in an official document of the State 
Council in June 1991, entitled, Notice on Keeping the Reform of the Urban Housing System Stable and Active. In the document, it was stated that 'Economical commodity housing should be pushed forward and the households without dwellings or with a serious housing shortage have a priority'.' On July 18, 1991, the State Council further pointed out in another official document entitled, Decision on Deepening the Reform of the Urban Housing System, that 'Every local government should pay more attention to developing and building economical housing to speed up the resolution of the problem of housing shortages for middle and lower-middle income households.' On January 20, 1995, the National Comfortable Housing Project Implementation Scheme was put forward by the team leading the reform of the housing system in the State Council. The implementation of the National Comfortable Housing Project was set up as a main instrument for the production of economical housing. On July 3, 1998, the State Council further announced in a document entitled, Notice on the Further Deepening of the Reform of Urban Housing System and Speeding Up the Building of Housing, that 'Building and perfecting a new housing provision system with economical housing as its main part; put different housing policies into different households according to their income level; the lowest income households rent low-rental housing from government or work units, middle and low-income households purchase economical housing, high-income households purchase or rent market price commodity housing'. At that time, policies on the building of economical housing were nailed down as a main channel for providing housing to urban residents and a new engine for economic growth (Feng, 1999).

\subsection{The First Phase: A Brief Introduction to the National Comfortable Housing Project}

The National Comfortable Housing Project was a housing project carried out by the cen- tral government from 1995 to 1998 as a very important instrument to push forward the reform of urban housing. Under the project, the central government invested over 220 billion $\mathrm{RMB}$ and provided over 260 million square metres of floor area to households. In Beijing city, about 52,000 households with a per capita floor area of less than 4 square metres had their living standards improved (Wong et al., 2003). In the whole nation, the housing conditions of about 0.65 million households were improved. During the period of the implementation of the National Comfortable Project, the old system of allocating welfare housing was still at work, but the new system of market housing was gradually taking shape. On the one hand, the Chinese government had invested a large sum of money to build affordable housing to ease the serious shortage of housing accumulated since the 1950s. On the other hand, the government encouraged people who became rich first to buy housing in the market and, at the same time, adopted many measures to prepare for the shift from the old system of housing to the new one. The experience gained from implementing the National Comfortable Housing Project subsequently became the basis for designing policies on the system for economical housing.

\subsection{The Second Phase: 1998-2002, the Take-off Phase of Economical Housing}

In 1998, China's economy faced the challenges of external environment disrupted by the financial crisis in Southeast Asia. The Chinese government adopted an active financial policy to ease the effects of the Asian financial crisis. Increasing investment, especially in economical housing, to stimulate economic growth was one of the methods adopted to achieve the objective of a GDP growth rate of $8 \%$.

In July 1998, the Chinese government put forward the plan to abandon the old system of allocating welfare housing and spur the development of economical housing. Each local gov- 
ernment was asked by the central government to support the building of economical housing by improving development conditions and providing financing. In the first six months of 1998, the central government devised two sets of investment plans. The total investment for both plans combined was 89.75 billion RMB and the floor area was 106.94 million square metres - more than the volume for the past three years under the National Comfortable Housing Project. Then, in the second half of 1998, the third economical housing investment plan was drawn up. This time, the investment was as high as 80.58 billion RMB and the floor area was 105.49 million square metres. In Over 71 billion RMB of the investment came from bank loans and the rest was raised by local governments and developers. As shown in Figure 2, investment in economical housing was maintained at a high level under the guidance of the central government in the following four years (1999 2002). In 1999, the investment was 190.13 billion RMB and the floor area was 244.4 million square metres. In 2000, it was 188.9 billion RMB and 242.7 million square metres; and in 2001, 169.9 billion RMB and 225.5 million square metres. In 2002 , investment slowed to 157 billion RMB and 209.5 square metres.

\subsection{A New Driver of the Economy}

The economical housing system has a close relationship with two of the three main factors that can drive economic growth. These are investment and consumption. The Chinese government is fully convinced of the contribution of the development of economical housing to economic growth. According to the National Statistics Bureau, every 100 RMB of housing investment can bring about 150 to $170 \mathrm{RMB}$ of demand in related industries. Table 3 indicates that from 1998 to 2002 , investment in economical housing investment took up an average of 1.97\% of GDP. In 1998, 1999 and 2000, the proportions were all over $2 \%$. It then peaked in 1999 at $2.32 \%$. In 2001 and 2002, investment in economical housing declined, but economic growth remained strong. The dependence of economic growth on investment in economical housing is decreasing along with the ripeness of the housing market.

Table 4 indicates that from 1998 to 2001, the total sales area of economical housing reached 121.49 million square metres, accounting for $20.14 \%$ of the total residential sales area transacted. Over 1.5 million middle and lower-middle income households purchased economical houses. The average price of eco-

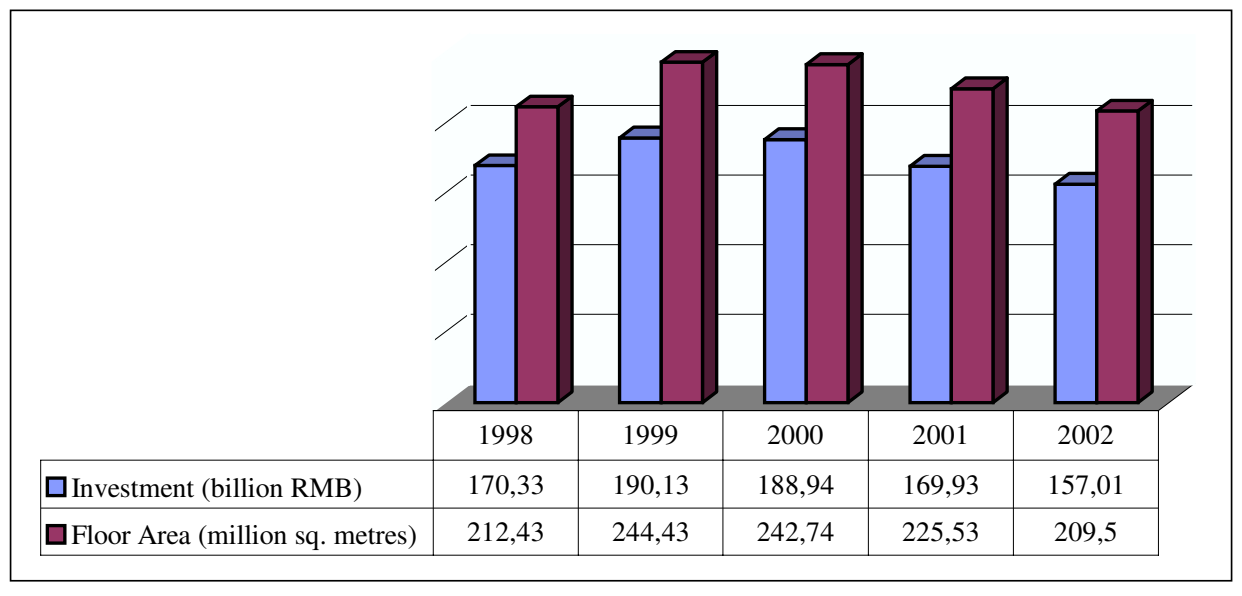

(Source: The economical housing annual investment guidance plan of the MOC 1998 2002)

Figure 2. National Investment in Economical Housing in China (1998 2002) 
Table 3. The Relationship between Investment in Economical Housing and Economic Growth

\begin{tabular}{llll}
\hline Year & GDP (billion RMB) & $\begin{array}{l}\text { Economical Housing } \\
\text { Investment (billion RMB) }\end{array}$ & Proportion in GDP \\
\hline 1998 & 7955.3 & 170.33 & $2.14 \%$ \\
1999 & 8205.4 & 190.13 & $2.32 \%$ \\
2000 & 8940.4 & 188.94 & $2.11 \%$ \\
2001 & 9593.3 & 169.93 & $1.77 \%$ \\
2002 & 10239.8 & 157.01 & $1.53 \%$ \\
\hline
\end{tabular}

(Source: China Statistics Yearbooks 1998 to 2001. Data of 2002 from the website of the China Statistics Bureau)

Table 4. Sales Area of Economical Housing

\begin{tabular}{llll}
\hline Year & $\begin{array}{l}\text { Sales Area of E.H. } \\
\text { (million sq. metres) }\end{array}$ & $\begin{array}{l}\text { Sales Area of Residence } \\
\text { (million sq. metres) }\end{array}$ & Proportion of E.H. \\
\hline 1998 & 16.67 & 108.27 & $15.4 \%$ \\
1999 & 27.01 & 129.98 & $20.78 \%$ \\
2000 & 37.60 & 165.70 & $22.69 \%$ \\
2001 & 40.12 & 199.47 & $20.11 \%$ \\
\hline Total & 121.49 & 603.42 & $20.14 \%$ \\
\hline
\end{tabular}

(Source: Yearbooks of China Real Estate Market 2000 to 2001)

nomical housing was $1,143 \mathrm{RMB}$ per square metre, equivalent to $60 \%$ of the average price of residential housing, which was 1,919 RMB per square metre.

\section{RELEVANT POLICIES ON THE SYSTEM OF ECONOMICAL HOUSING IN BEIJING}

The general guidance on economic housing comes from the central government. However, considering the regional character of the real estate market, local governments are permitted to frame detailed local policies, regulations and institutions. Economical housing is thought of as pre-commodity housing. As shown in the following table, the policies on economic housing in Beijing differ to some extent from the policies on commodity housing.

\subsection{Land Usage}

The land for building economical housing is granted administratively by local governments to developers without any charge. Governments try to cut the price of economical housing by remitting taxes and fees.

\subsection{Prices}

The prices of economical housing in Beijing are restricted by two sets of regulations. One is The Management Regulation of Economical

Table 5. Policy Differences between Economical Housing and Commodity Housing

\begin{tabular}{lll}
\hline Policies & Economical Housing & Commodity Housing \\
\hline Land Supply & Government & Land Market \\
Price & Government & Developers \\
Ownership & With Limitations & Full \\
Property Management Price & Government & Property Management Companies \\
\hline
\end{tabular}

(Source: MOC and Beijing Government Documents) 
Housing Price, which was drawn up by the Ministry of Construction (MOC) and State Development Planning Commission, and implemented on January 1, 2003. On the basis of this national regulation, the government of Beijing drew up complementary regulations for Beijing.

The price of economical housing is a government recommended price which consists of the development cost, taxes and profit. Developers are requested to keep a low profit in order to ensure affordability for middle and lower-middle income urban households. They are also required to keep the price different from commodity housing, in order to reflect the preferences according to economical housing by the government. The prices for economical housing projects need to be endorsed by the governmental price management department and announced to the public before the projects commence. Other charges such as the cost of building and maintaining structures for business purposes or for the use of the developer, and any penalties, should not be included in the housing price. When the economical housing units are sold, the prices can be adjusted upwards or downwards according to floor level and orientation. But the scope of the adjustment should not be more than $3 \%$ and the total sum charged for the whole building should remain the same after the adjustment. The way in which the prices for economical housing are fixed before the commencement of the projects can control the profits of the developers and also the basic building costs.

With the aim of keeping expenditures lower than those for commodity housing to enable more middle and low-income households to own their homes, 21 transfer charges, which are very high in China, such as the deed tax, administrative fees, agency fees and stamp duty have been either reduced or exempted. The low transfer charges have had a positive impact on sales of economical housing.

\subsection{Ownership}

Full housing property rights in China include four attributes: the right to own, the right to use, the right to transfer and the right to obtain a profit. Commodity housing has all of these four attributes. It can be sold, rented or given without limitation and passed down from anybody or any organization. Proceeds belong totally to the owner. For the purchaser, there is no other charge except taxes. According to the relevant regulations of the Beijing government, the property rights for economical housing in Beijing share the same attributes as those for commodity housing, with one difference. The difference is that the purchaser should be able to afford the land tenure charge, which is $10 \%$ of the local basic land value. If there is no basic land value as a standard, the land tenure charge should be set at $3 \%$ of the sale price of the economic housing unit. Thus, the purchaser gets a commodity housing property with full equities after the transfer procedure. If the property is sold once more, there is no longer any need to pay the land tenure charge.

\subsection{Property Management}

A social, professional and marketization mechanism for the property management of economical housing has been adopted. Property management companies have been competing with each other to be appointed by owner-committees. The property management charge for economical housing is unified by local governments according to affordability for local residents and level of management. In Beijing, owners of economical housing pay a property management charge of $0.50 \mathrm{RMB}$ (lower than $30 \%$ with the green cover rate) or 0.52 RMB (higher than $30 \%$ with the green cover rate) per square metre per month. The services include: the cleaning of public areas inside the economical residential districts, security, gardening, ordinary management and ordinary maintenance of the buildings, facilities and public structures. An extra charge of 
0.47 to $0.56 \mathrm{RMB}$ per square metre per month is levied if the building has facilities such as lifts and water pumps.

In 1997, the Beijing government joined forces with Tsinghua University and Beijing Real Estate Association to investigate models for property management charges. Twentyeight common residential districts were selected as samples. The floor area involved was 2.93 million square metres. One of the conclusions was that the cost charge of normal residential property management in Beijing was $1.62 \mathrm{RMB}$ per square metre per month. Therefore, the property management charge of economical housing is far below the cost. The rate is entirely an administrative price decided by the local government.

\section{THE SUPPLY OF ECONOMICAL HOUSING IN BEIJING FROM 1998 TO 2002}

\subsection{Economic Housing Projects Developed in Beijing (1998-2002)}

The economical housing projects have been marketed in Beijing since October 29, 1998. The first batch consisted of 23 projects. But four of them were not for public sale. Others started being built in 1998 and 1999. The unquestionably lower prices compared with the commodity housing in the same location caused most of the first batch of projects to sell out very quickly. In 2000 and 2001, no new economical housing projects went on the market in Beijing. One of the reasons was the shortage of the stock of land for economical housing, due to the hardship caused by land expropriations. Another reason was that strict public bidding regulations on the design and construction of economical housing prolonged the development cycle. The completed area in these two years all stemmed from the old projects under construction. By the end of $2002 £ \neg$ the number of economical housing projects completed or under construction rose to 39 . Of these, 32 projects were sold to public. Nine have been totally completed, with a floor area of 9.3 million square metres.

\subsection{The Proportion to Housing Supply in the Market}

Figure 3 shows that the supply of economical housing has increased year by year since

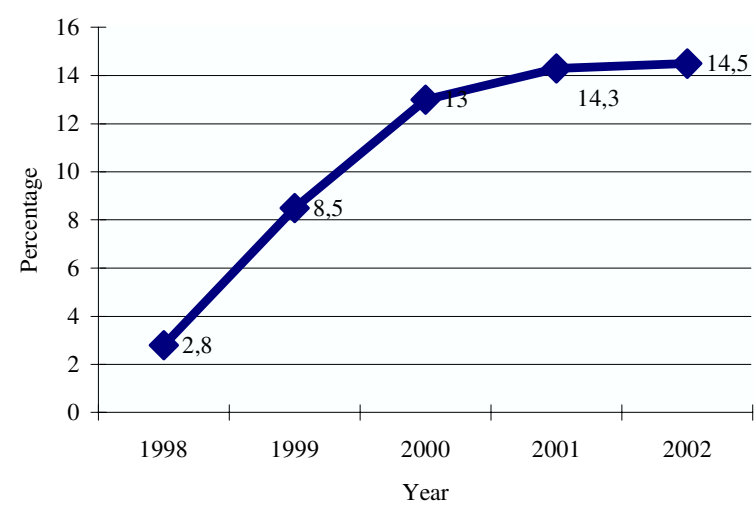

(Source: Beijing Real Estate Yearbooks of 1998 1999 and the website of the Beijing Construction Commission)

Figure 3. The Increase in the Supply of Economical Housing in Beijing

Table 6. Production of Economical Housing in Beijing (1998 2002)

\begin{tabular}{llll}
\hline & $\begin{array}{l}\text { Completed Area of } \\
\text { Economical Housing } \\
\text { (million sq. metres) }\end{array}$ & $\begin{array}{l}\text { Completed Areaof Total } \\
\text { Housing Supply } \\
\text { (million sq. metres) }\end{array}$ & $\begin{array}{l}\text { Proportion of Economical } \\
\text { Housing (\%) }\end{array}$ \\
\hline 1998 & 0.31 (Comfortable Housing) & 10.93 & 2.8 \\
1999 & 1.29 & 15.20 & 8.5 \\
2000 & 1.96 & 15.00 & 13.04 \\
2001 & 2.58 & 18.05 & 14.3 \\
2002 & 3.16 & 21.90 & 14.5 \\
\hline
\end{tabular}

(Source: China Real Estate Statistics Yearbooks 1999 to 2001. Data of 2002 from the website of the Beijing Construction Commission) 
1998. In 2002, its proportion of the total supply of residential housing rose to $14.5 \%$. But the proportion is still nowhere near the level considered desirable by the government. This level is regarded by some policy makers as being $60 \%$. Some even believe that it should be $80 \%$.

\subsection{The Location of Economical Housing Projects}

In Beijing, land prices are mainly determined by the location and the distance to the city centre. Because of the price limit for economical housing, most of the first batch of economical housing projects was built in suburban areas. The average distance of these economical housing projects from the city centre is about 10 kilometres. But all of the areas where the projects are located are well planned with good infrastructural support. The development of these economical housing projects has also accelerated the process of urbanization. Traffic, civic infrastructure and environments have all improved. See Table 7.

\subsection{Price Study}

In Table 8, average prices in Beijing's real estate market reached an all-time high, with the exception of 2002 , because of the city's special social and economic situation. In 1997, the average price of residential housing in the country was $1,790 \mathrm{RMB}$ per square metre, but 5,478 RMB per square metre in Beijing - three times as high as the national average price for residential housing. It is also much higher than the average price in Shanghai of 2,891 RMB per square metre. As shown in Figure 4, from 1998, when the policies on economical housing were implemented, to 2002, the average housing price for the nation was very stable, rising but at a slower pace. The average price for housing in Beijing remained flat, and then exhibited a downward trend after 1999, with a sharp decrease in 2002. In Shanghai, the average housing price has been increasing continuously, with a sharp increase to $4,803 \mathrm{RMB}$ per square metre in 2002 , even higher than that in Beijing. Beijing and Shanghai are the most important real estate markets in China. However, the governments of

Table 7. Location Analysis of Economical Housing Projects in Beijing (1999

\begin{tabular}{llllll}
\hline Location & $\begin{array}{l}\text { Inside } 2^{\text {nd }} \\
\text { Ring Road }\end{array}$ & $\begin{array}{l}2^{\text {nd }} \sim 3^{\text {rd }} \\
\text { Ring Road }\end{array}$ & $\begin{array}{l}3^{\text {rd }} \sim 4^{\text {th }} \\
\text { Ring Road }\end{array}$ & $\begin{array}{l}4^{\text {th }} \sim 5^{\text {th }} \\
\text { Ring Road }\end{array}$ & $\begin{array}{l}\text { Outside } 5^{\text {th }} \\
\text { Ring Road }\end{array}$ \\
\hline $\begin{array}{l}\text { Economical } \\
\text { Housing Project }\end{array}$ & 0 & 1 & 1 & 10 & 3 \\
$\begin{array}{l}\text { number } \\
\begin{array}{l}\text { Commercial } \\
\text { Housing Project } \\
\text { number }\end{array}\end{array}$ & 49 & 76 & 70 & 21 & 10 \\
\hline
\end{tabular}

(Source: Beijing Construction Commission)

Table 8. Annual Average Residential Price (RMB)

\begin{tabular}{lllllllll}
\hline Year & 1995 & 1996 & 1997 & 1998 & 1999 & 2000 & 2001 & 2002 \\
\hline The State & 1,509 & 1,605 & 1,790 & 1,854 & 1,857 & 1,948 & 2,017 & 2,227 \\
Beijing & 3,418 & 3,869 & 5,478 & 4,769 & 4,787 & 4,771 & 4,716 & 4,467 \\
Shanghai & 2,477 & 2,968 & 2,891 & 3,026 & 3,102 & 3,326 & 3,659 & 4,803 \\
\hline
\end{tabular}

(Source: China Real Estate Statistics Yearbooks 1999 to 2001. Data of 2002 from the website of the Beijing Construction Commission) 
Table 9. Compared with the Price of Commodity Housing in Beijing

\begin{tabular}{llllll}
\hline Year & 1998 & 1999 & 2000 & 2001 & 2002 \\
\hline E.H. Average Price (RMB per sq. metre) & $1,109^{*}$ & 2,664 & 2,748 & 3,000 & 3,100 \\
C.H. Average Price (RMB per sq. metre) & 4,769 & 4,787 & 4,771 & 4,716 & 4,467 \\
\hline Price Difference (RMB) & 3,660 & 2,123 & 2,023 & 1,716 & 1,367 \\
\hline
\end{tabular}

(Source: China Real Estate Statistics Yearbooks 1999 to 2001. Data of 2002 from the website of the Beijing Construction Commission)

Table 10. Prices for Economical Housing in Beijing

\begin{tabular}{lll}
\hline Price $(\mathrm{RMB})$ & $\begin{array}{l}\text { Project } \\
\text { Numbers }\end{array}$ & $\begin{array}{l}\text { Ratio in Total } \\
\text { Projects }\end{array}$ \\
\hline $2,280 \sim 2,500$ & 4 & $9.5 \%$ \\
$2,500 \sim 3,000$ & 6 & $14.3 \%$ \\
$3,000 \sim 3,500$ & 7 & $16.7 \%$ \\
$3,500 \sim 4,000$ & 17 & $40.5 \%$ \\
$4,000 \sim 4,500$ & 5 & $11.9 \%$ \\
$4,500 \sim 4,850$ & 3 & $7.1 \%$ \\
\hline
\end{tabular}

(Source: China Real Estate Statistics Yearbooks 1999 to 2001. Data of 2002 from the website of the Beijing Construction Commission)

the two cities have a substantially different attitude towards economical housing. The policies on economical housing were not implemented at all in Shanghai but strongly pushed forward in Beijing. Because of the restriction on price, the average price for economical housing in Beijing is lower than the average residential housing price (refer to Tables 9 and 10). The average price difference is $1,807 \mathrm{RMB}$ per square metre. Nearly $93 \%$ of economical housing is priced lower than the average price for residential housing (refer to Table 10). This has dragged down the average price of residential housing in Beijing.

\section{THE CURRENT DEMAND FOR ECONOMICAL HOUSING IN BEIJING}

In 1999, the first economical housing project, consisting of 10,000 square metres, sold out in just a month. From then on, almost every economical housing project has led to a flood of reservations, indicating a huge demand for economical housing in Beijing.

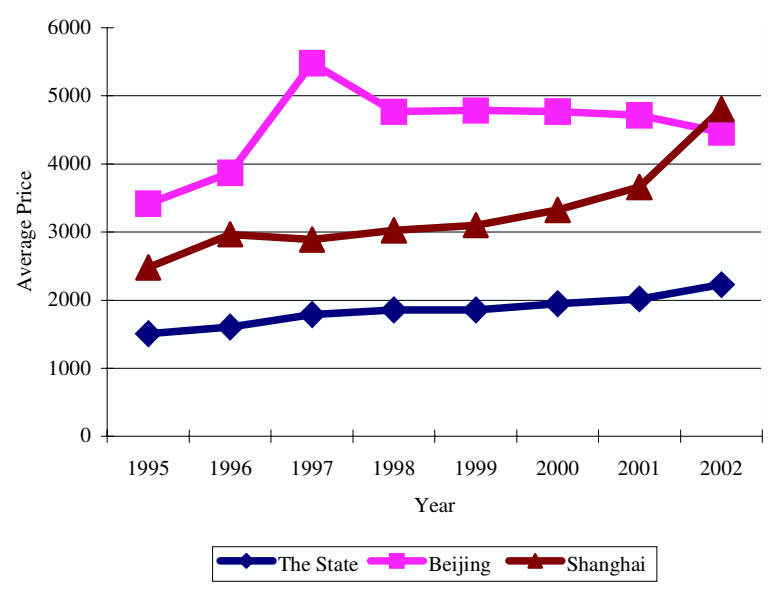

(Source: China Real Estate Statistics Yearbooks 1999 to 2001. Data of 2002 from the website of the Beijing Construction Commission)

Figure 4. The Trend in Residential Housing Prices, 1995 2002

\subsection{The Demand for Urban Renewal and Resettlement}

Economical housing has to address several needs. The most urgent is how to satisfy the huge demand for urban renewal. Thousands of people need to be evacuated from their homes and resettled elsewhere. In 1998, the number of such households was over 8,000 . In 2001 , over 90,000 households were evacuated and in 2002 , up to 70,000 . Over $60 \%$ of the evacuated households were resettled by purchasing economical housing. There are 164 blocks, consisting of about 3.03 million square metres of old and dilapidated housing in Beijing at present. All of them are in the city centre. The local government plans to complete the work of renewal before 2005. About 9.34 
million square metres of housing need to be demolished and 347,000 households have to be relocated. Both the Beijing municipal government and the developers want to build commodity housing on the land after renewal and to relocate most of the original residents. The average number of households involved in each year of the coming four years is about 70,000. Even the compromise practice of giving at least $30 \%$ of the inhabitants a chance to move back at a subsidized price after renewal, is difficult to attain since greater profits can be realized if more of the original residents can be replaced by high-paying buyers of commodity housing and commercial space (Nilsson, 1998). It is assumed that if $50 \%$ of these households want to purchase economical housing and the smallest size of a housing unit is 70 square metres, at least 2.5 million square metres floor area of economical housing will be needed annually in the following four years. Judging from the statistics at the beginning of 2002, the supply of economical housing within the coming four years will be far from meeting the demand (Beijing Daily, 2003.04.22).

\subsection{The Increasing Percentage of Individual Purchasers of Housing}

For many years, institutions such as government departments, state-owned enterprises and institutes were the dominant buyers of residential housing in Beijing. Before 1999, civil servants and workers in large-sized stateowned enterprises usually rented apartments from their work units at a very low cost as a kind of welfare provision. Organizations purchased up to $80 \%$ of the housing on the market. Such organizations seldom considered price as an important factor. In 1999, the old housing allocation system was abolished. Since then, the percentage of individual purchasers of housing has been increasing continuously. As shown in Figure 5, from 1998 to 2002, the rate increased from $40.3 \%$ to $95.3 \%$. Price and quality have become the most important factors. Economical housing offers the same planning and construction standards as commodity housing, but at a much lower price. Thus, it has become the most attractive choice for individual purchasers.

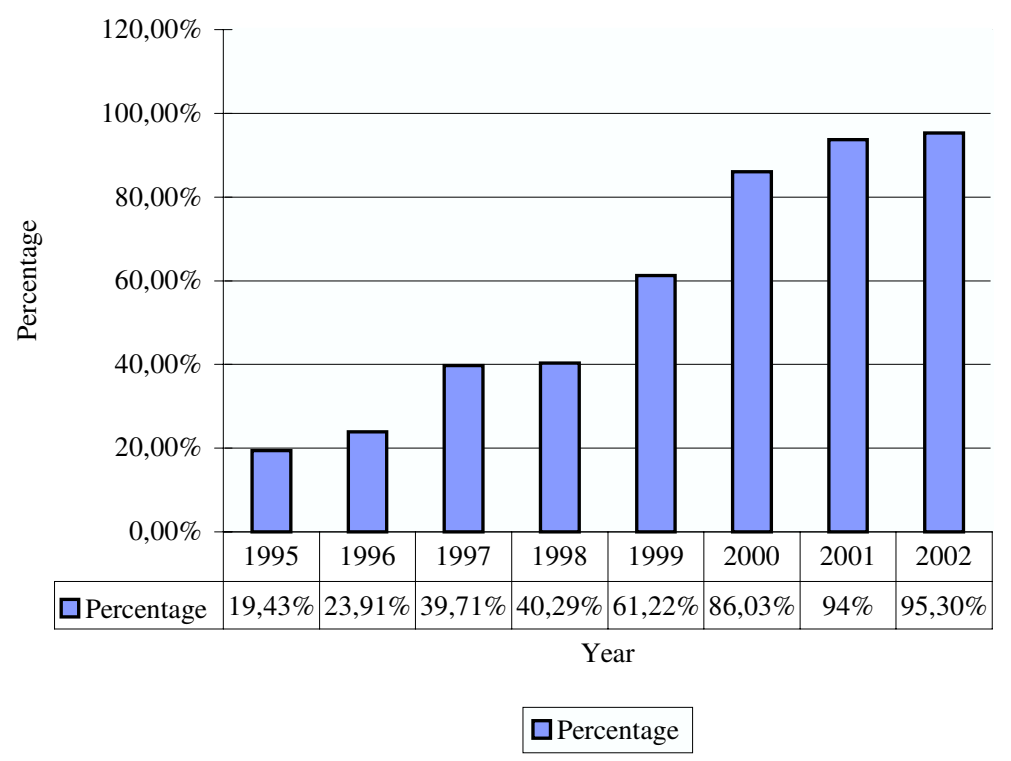

(Source: China Real Estate Statistics Yearbooks 1999 to 2001. Data of 2002 from the website of the Beijing Construction Commission)

Figure 5. The Increasing Percentage of Individual Purchasers of Housing 

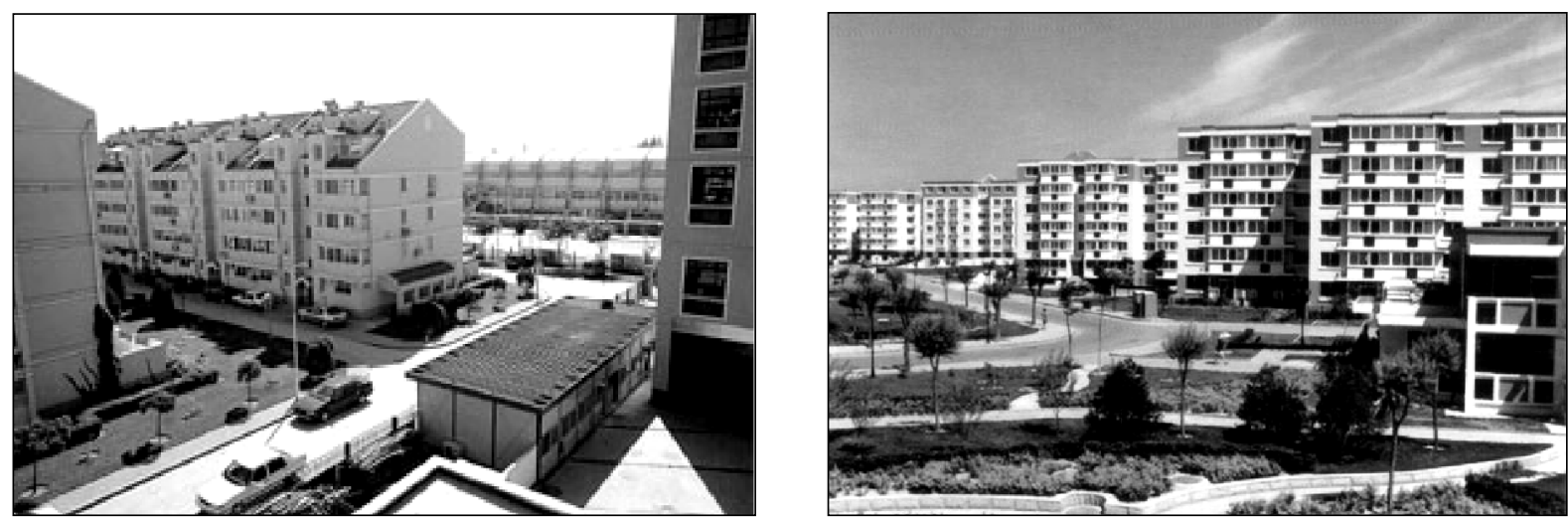

(Source: www. hlgnet.com)

Figure 6. Hui Long Guan Cultural Residential Community

\section{PROBLEMS WITH THE DEVELOPMENT OF ECONOMICAL HOUSING}

In order to discover the problems and obstacles involved in the development of economical housing, a case study was carried out on an economical housing project called Hui Long Guan Cultural Residential Community. It is the biggest economical housing project in Beijing as well as in the whole nation. The motivation for building such a large residential district is to provide enough housing to employees who work in universities, research institutes and hospitals in the north-western part of the city. The Hui Long Guan Cultural Residential Community is located in Changping District, a suburb in the far north-western section of Beijing. The Beijing municipal government granted about 141 ha of land. At the time, only one or two bus routes passed through the area. The government and the developer invested over 0.5 billion RMB in preparing the land. The workload involved in the project was similar to that of developing a new town. The general situation of the project is shown below.

Table 11. The Nature of Hui Long Guan Cultural Residential Community

\begin{tabular}{ll}
\hline Location & $\begin{array}{l}\text { Changping District; Outside the 5th ring road; About } 15 \text { kilometres away } \\
\text { from the city centre. }\end{array}$ \\
\hline Transportation at present & $\begin{array}{l}6 \text { bus lines pass by; } 30 \text { minutes by the inner-city train from the } 2^{\text {nd }} \text { ring } \\
\text { road. } 10 \text { minutes by car along the highway from the } 4 \mathrm{t}^{\mathrm{h}} \text { ring road. }\end{array}$ \\
Planned gross floor area: 8.5 million sq. metres. \\
Planned number of inhabitants: 0.3 million.
\end{tabular}

(Source: www. hlgnet.com) 
Table 12. Sizes of House Units in Hui Long Guan Cultural Residential Community (Phase 1)

\begin{tabular}{lll}
\hline Type of Housing unit & Gross Floor Area of Unit (sq. metres) & The Proportion of Each Type \\
\hline One-bedroom units & 75.70 & $10 \%$ \\
Two-bedroom units & $84.09 \sim 105.52$ & $25 \%$ \\
Three-bedroom units & $104.11 \sim 147.62$ & $35 \%$ \\
Four-bedroom units & $131.85 \sim 187.61$ & $25 \%$ \\
Two-floor units & $147.25 \sim 300.67$ & $5 \%$ \\
\hline
\end{tabular}

(Source: www. hlgnet.com)

\subsection{The Problem of Oversized Housing Units}

The size of each economical housing unit has no upper limit; thus, some economical housing units are extravagantly large. Table 12 shows that over $65 \%$ of the units in Hui Long Guan (Phase I) are over 100 square metres. The larger the size of a housing unit, the higher is its gross price. Thus, although the price per square metre is as low as 2,600 $\mathrm{RMB}$, the gross price of a 150 square metre unit is still as high as 390,000 RMB. It is difficult for middle-income households to afford. At the same time, the number of housing units that can be built under a fixed general floor area is insufficient. Such a problem is common in most economical housing projects. If the problem of oversized units in economical housing projects continues in the future, the conflict between the insufficient construction capacity of economical housing and the huge demand will obviously grow.

\subsection{The Difficulty of Identifying Target Groups}

Although economical housing is provided to middle and lower-middle income households, until the end of 2001, no specific income limits had been set for target households in Beijing. Therefore, there was no limit to the households purchasing flats in the first and second phases of Hui Long Guan. The majority of the housing purchasers are not middle or lower-middle income households, but those in the higher income groups. In the first phase of Hui Long Guan, 30\% of the purchasers are employees of large foreign-invested companies and big private companies who, after the implementation of economic reforms, earn the highest salaries in Beijing. In another economical housing project, Bei Lu Yuan, nearly $80 \%$ of the purchasers are business owners (Zhu, 2001). This situation seriously damaged the concept of equity in the system of economical housing. By the end of 2001, the Beijing government set up an income limit for economical housing. The households with annual income of more than $60,000 \mathrm{RMB}$ are excluded from buying economical housing. Purchasers of economical housing must provide an income certificate from their employers confirming this fact. The purchase is permitted after the certificate is verified. This measure did help to some extent to identify the target purchasers of economical housing. But given the opacity regarding information on income in China, the difficulty of identifying the buyers remains the main problem for economical housing.

\section{CONCLUSION AND RECOMMENDATIONS}

\subsection{Activating the Housing Market and Acting as the Engine for Economic Growth}

With economic growth and reform, the changes in China's housing system have been dramatic. A new housing provision system, with the economical housing as its pillar, has been set up. The government has forcefully pushed forward the development of economical housing by granting land and reducing ad- 
ministrative charges. The government has also enabled the target group of such housing by limiting price of economical housing, cutting construction costs, capping the profits from economical housing, as well as guaranteeing an easy mortgage loan from banks and housing allowances to individual homebuyers. The good progress in the development of economical housing has activated the residential housing market by matching housing prices with the affordability of the majority of the homebuyers. The financing of private housing has grown from a negligible amount five years ago to more than 660 billion RMB (US $\$ 80$ billion) today, accounting for 10 per cent of all of China's bank loans. Much of the spending on housing is based on real demand and involves related expenditures. The measure has spurred economic growth, as well as provided houses for urban residents following the ending of the old housing allocation system in 1999. The floor area per capita for urban residential housing has increased from 17.6 square metres to 22 square metres in the past five years. The average floor area of every household is about 70 square metres in 2002 , basically satisfying the demand for housing. The amenities in residential housing and the public facilities have also improved significantly. Thus, economical housing is playing a very important economic and social role in China.

\subsection{Imperfect Implementation}

The defects in the system of providing economical housing that have been present from the very beginning have drawn criticism. Although the policy of economical housing is sound in principle, there are still problems with the process of sale. The most acute problem is that many people with a high level of income have been able to buy economical housing because of the lack of a reliable system of differentiating the rich from the poor. In some of the economical housing projects in Beijing, luxury cars are not rare; some people even own several apartments in one community. Wealthy people who have purchased economical housing have not only taken away resources from the state, but have also had a negative impact on the sale of commodity housing. This has damaged the viability of the entire residential housing market. Another problem is that developers of economical housing keep building oversized units to satisfy the preferences of rich purchaser in order to make greater profits. If such loopholes are not closed, economic housing will not go to where it is most needed.

\subsection{Recommendations for a Bright Future}

The system of providing economical housing should be continued for the long term. 'If there is one single factor that has saved the world economy from a deep recession it is the housing market.' This observation by Tim Bellman, principal economist at Jones Lang LaSalle, is pertinent. The system of providing economical housing has brought a large amount of affordable housing to the housing market. This has stimulated the housing market and will help it to grow and mature. Also in this way, the housing market can avoid shocks and development will remain stable for a long time under the macro control of the government. The system of providing economical housing as the pillar of the new system of housing provision system in China will not only help middle and lower-middle income households to improve their standard of housing, but also help to form and develop a structure for the consumption of housing in the entire society. Therefore, the existence and development of the system of providing economical housing should be long-term and impersonal. This also is proved by the experiences of some developed countries and cities. Such government-subsidized housing systems have existed in the United States, Hong Kong and Singapore for many years, and have played an important role in the housing markets and economies of those countries.

The target groups must be made clear 
as soon as possible. The aim of the policy of economical housing is to benefit middle and lower-middle income households by addressing their housing problems. The range of those targeted should be identified. The standard should be set up according to the local economic level, general housing conditions and the financial ability of the local government. A strictly limited target group is desirable at present.

The policies on economical housing should be dynamic and shift with economic growth and improvements in living standards in the country. The policies on economical housing should develop along with the economy. As a long-term approach, the concept of the economical housing is dynamic, although stable in specific periods. The building standards of economical housing, including the unit size of homes, environment, greenery, construction materials and construction technology should also be updated continuously.

\section{Acknowledgements:}

This research was funded by the Hong Kong Polytechnic University (Research account 202Z).

\section{REFERENCES}

Bao, Z. H. (2002) Economical Housing Development. Urban and Rural Development, 2002 01, p. 245.

Beijing Real Estate Yearbooks (1998 1999), China Publishing House of Planning, Beijing, Beijing.

Cheng, S. W., Wang, Z., Hong, Y. M., Lin, J., Liu, H. Y., Dong, L. M., Wang, E. P., Wen, K., Lin, Z. J., Feng, Z. F., and Feng, C. C. (1999) China urban housing system reform: targets and obstacles, Beijing: Democratic Building Publishing Limited (in Chinese).

China Real Estate Statistics Yearbooks (1999 2001), China Urban Publishing House, Beijing.

Di, H. (2003) Identify the Middle Income Level Reasonably, the Middle Income Household Per Capita Income Should Be 10000 40000 RMB. Economic Information Daily, 2003-02-13 (in Chinese).

Feng, C. C. (1999) A Critical Review of Affordable Decent Housing Policies in Urban China. City Planning Review, 23(8), p. 18-20 (in Chinese).

Jin, Y., Liu, W. N. (1999) The Development of the Economical Housing in Beijing. Beijing City Planning and Construction Review, Vol. 5, p. 53-55.

Nilsson, J. (1998). Problems and Possibilities in Today's Urban Renewal in the Old City of Beijing. City Planning, No. 4, p. 42-46.

The Statistical Communiqués of the Beijing Statistics Bureau (1999 2002) (in Chinese).

Wong, F., Hui, E. and Meng, F.Y. (2003) A Review on the National Comfortable Housing Project in China — A Case Study of Beijing, Paper Presented at the $3^{\text {rd }}$ China Urban Housing Conference, Hong Kong, 10 pp.

Yearbook of China Real Estate Market (2000 2001). (2001) China Publishing House of Planning, Beijing (in Chinese).

Zhang, D. L. (2003) Economical Housing in Beijing. China Newspaper of Construction, on 2003.06.04, Beijing.

Zhang, N. P. (2002) Checking Economical Housing Projects in Beijing. Beijing Real Estate, Vol. 3, p. 15-17.

Zhu, F. (2001) Forecasts, Analyses and Proposals for Economical Housing in Beijing. Beijing Real Estate, Vol. 5, p. 12-17 and Vol. 6, p. 8-9.

Zhu, J. M. (2000) The Changing Model of Housing Provision in Transitional China. Urban Affairs Review, 35(4), p. 502-519. 